Turkish Psychological Counseling and Guidance Journal

Türk Psikolojik Danışma ve Rehberlik Dergisi
Karagöz, Durak \& Mutlu (2021)

Vol: 11 Number: 62 Page: 403-417 ISSN: 1302-1370

RESEARCH

Open Access

ARAŞTIRMA

Açık Erişim

\title{
Psychological Resilience and Life Satisfaction of Healthcare Professionals in Turkey: The Mediating Role of Fear of COVID
}

\author{
Türkiye'de Sağlık Çalışanlarmm Psikolojik Sağlamliğı ve Yaşam Doyumu: COVID-19 Korkusunun Aracılık. \\ Rolï
}

\section{Yalçın Karagöz $\bullet$, İsmail Durak $\bullet$, Hakan Tahiri Mutlu}

\begin{tabular}{l}
\hline Authors Information \\
Yalçın Karagöz \\
Professor, Düzce University, \\
Düzce, Turkey \\
yalcinkaragoz@,duzce.edu.tr \\
İsmail Durak \\
Assistant Professor, Düzce \\
University, Düzce, Turkey \\
ismaildurak@duzce.edu.tr \\
Hakan Tahiri Mutlu
\end{tabular}

Tahiri Mutlu

Assistant Professor, Bolu Abant

İzzet Baysal University, Bolu,

Turkey tahirimutlu@ibu.edu.tr

\begin{abstract}
COVID-19 pandemic has caused devastating consequences as psychological traumas especially for healthcare professionals, who play an active role and are at greatest risk in this process. It is important to protect their health to prevent the health system from collapsing. The purpose of this study is to reveal the mediating role of coronavirus fear in the effect of psychological resilience on life satisfaction. coronavirus fear, psychological resilience, and life satisfaction scales were applied to 414 healthcare professionals in 36 provinces of Turkey. The findings show that the increase in the fear of coronavirus decreases the levels of psychological resilience and life satisfaction, whereas the increase in psychological resilience increases the level of life satisfaction. The results suggest that coronavirus fear may contribute to understanding the association between psychological resilience and life satisfaction among healthcare professionals.
\end{abstract}

\begin{tabular}{l}
\hline Article Information \\
\hline Keywords \\
Fear of COVID-19 \\
Psychological Resilience \\
Life Satisfaction \\
Path Analysis \\
Healthcare Professionals \\
Anahtar Kelimeler \\
COVID-19 Korkusu \\
Psikolojik Dayanıklılık \\
Yaşam Doyumu \\
Yol Analizi \\
Sağlık Çalışanları \\
Article History
\end{tabular}

\section{ÖZET}

COVID-19 salgını, özellikle bu süreçte aktif bir rol oynayan ve en büyük risk altında olan sağlık çalışanları için psikolojik travmalar gibi yıkıcı sonuçlara neden olmaktadır. Sağlık sisteminin çökmesini önlemek için sağlık çalışanlarının sağlıklarını korumak önemlidir. Bu çalışmanın amacı, psikolojik sağlamlığın yaşam doyumu üzerindeki etkisinde koronavirüs korkusunun aracı rolünü ortaya çıkarmaktır. Türkiye'nin 36 ilinde 414 sağlık çalışanına koronavirüs korkusu, psikolojik sağlamlık ve yaşam doyumu ölçekleri uygulanmıştır. Bulgular, koronavirüs korkusundaki artışın psikolojik sağlamlık ve yaşam doyumu düzeylerini azalttığını, psikolojik sağlamlık düzeyindeki artışın ise yaşam doyumu düzeyini artırdığını göstermektedir. Sonuçlar, koronavirüs korkusunun sağlık profesyonelleri arasında psikolojik dayanıklılık ve yaşam doyumu arasındaki ilişkiyi anlamaya katkıda bulunabileceğini göstermektedir.

Received: 02/04/2021

Revision: $16 / 08 / 2021$

Accepted: 17/08/2021

Cite this article as: Karagöz, Y., Durak, I., \& Mutlu, H.T. (2021). Psychological resilience and life satisfaction of healthcare professionals in Turkey: The mediating role of fear of COVID. Turkish Psychological Counseling and Guidance Journal, 11 (62), $403-417$. https://doi.org/10.17066/tpdrd.1001724 


\section{INTRODUCTION}

Coronaviruses are a large family of viruses that can cause disease in animals or humans. Several coronaviruses are known to cause respiratory infections in humans ranging from the common cold to more severe diseases such as Middle East Respiratory Syndrome (MERS) and Severe Acute Respiratory Syndrome (SARS) (Guo et al. 2020; Holmes, 2003). Coronaviruses are a category of associated viruses that trigger diseases such as the coronavirus associated with the severe acute respiratory syndrome (SARSCoV) in 2003, human coronavirus NL63 (HCoV NL63) in 2004, human coronavirus HKU1 (HKU1) in 2005, respiratory syndrome-associated coronavirus in the Middle East (MERS- CoV) and coronavirus-2 (SARS-CoV-2) associated with severe acute respiratory syndrome in December 2019 (Amin, 2020). COVID-19, one of the types of coronaviruses, is an infectious disease caused by the most recently discovered coronavirus. The highly contagious nature of the disease has led to massive rates of infection and deaths (Chaudhary, 2020). This new virus and disease first appeared in Wuhan, China's Hubei province, in December 2019. After China, this virus, which has been seen in Iran since January 2020, has started to be seen in Italy and Spain. After the first case was detected in Europe, it started to spread almost all over the European continent in a short time like a month. On March 11, 2020, due to the disease becoming a pandemic that rapidly affects many countries around the world, a global epidemic was declared by the World Health Organization (WHO) with 114 countries affected by COVID-19. As of February 2021, 235 countries/regions around the world have been affected by the coronavirus (World Health Organization 2021). While the number of cases in the USA, which is one of the countries where the coronavirus causes great damage, was 27 million as of February 2021, this number reached 107 million worldwide, while the number of deaths from the coronavirus exceeded 2.4 million (https://covid19.who.int/). WHO announced the mortality rate from COVID-19 transmission as 2\% (WHO 2020c) and then updated this rate to 3\% (WHO, 2020d). In Turkey, the first cases were described on March 10, 2020. On 10 February 2021, the total number of cases approached 2.6 million and the total number of deaths approached 27 thousand (https://covid19.who.int/).

The most common symptoms of COVID-19 are fever, dry cough, and tiredness. Other symptoms that are less common and may affect some patients may include aches and pains, nasal congestion, headache, conjunctivitis, sore throat, diarrhea, loss of taste or smell, redness of the skin, discoloration of the fingers or toes. These symptoms are usually mild and begin gradually. Some people become infected but show very mild symptoms, while most (about 80\%) recover from the disease without the need for hospital treatment. Approximately 1 out of every 5 people who catch COVID-19 become seriously ill and have difficulty breathing. Older people and those with underlying medical conditions such as high blood pressure, heart, and lung problems, diabetes, or cancer have a higher risk of having the disease more severely (https://covid19.who.int/).

Many studies have been conducted on COVID-19. Some of these studies suitable for our research are as follows: Ahmed et al. (2020) aimed to assess the anxiety and fear of infection among dentists while working during the current outbreak of novel coronavirus diseases (COVID-19). In their research, they observed that although dentists around the world have a high standard of knowledge and practice, they are worried and fearful when working in their fields due to the pandemic effect of COVID-19 on humanity. However, they stated that some dental practices either changed their services according to recommended guidelines only for emergency treatment or closed their practices for an indefinite period. Amin (2020) used a qualitative and quantitative approach to measure the impact of the COVID-19 
pandemic on psychological well-being. According to the findings he obtained, he concluded that the fear of coronavirus continues in healthcare workers and causes various psychological symptoms on mental health. Arslan et al. (2020) examined the mediating role of optimism-pessimism and psychological flexibility in the relationship between coronaviruses stress and psychological problems of adults in Turkey. The results showed that coronavirus stress has a significant predictive effect on optimismpessimism, psychological resilience, and psychological problems. However, optimism-pessimism and psychological flexibility mediated the impact of coronavirus stress on psychological problems in adults. Finally, optimism-pessimism predicted the psychological problems of adults through psychological flexibility. Belen (2020) investigated the mental health aspects with the fear of COVID-19, namely the relationship between anxiety and depression and whether this relationship is through awareness. The results showed that fear of COVID-19 is inversely related to awareness, there is a positive correlation with anxiety and depression, and awareness is mediating the relationship between fear of COVID-19 and depression and anxiety. Doshi et al. (2020) used the COVID-19 Fear Scale (FCV-19S) to determine the COVID-19 fear levels of individuals in India and compare them with demographic variables. They concluded that women have higher levels of fear than men, married people than singles, individuals with low education levels than people with higher education levels, and healthcare workers than other occupational groups. Durmuss and Durar (2020) examined the relationship between the spiritual wellbeing levels of elderly individuals and their coronavirus fear levels during the COVID-19 pandemic. A significant negative correlation was found between the meaning and peace levels of elderly people and coronavirus fear levels. It has been observed that as the spirituality of individuals increases, their coronavirus fear levels decrease. Dymecka et al. (2020) tried to identify the relationship between fear of COVID-19, stress, sense of adaptation, and life satisfaction during the coronavirus epidemic. According to the findings, it was confirmed that the relationship between stress and life satisfaction was mediated by a sense of coherence, and the relationship between stress and sense of adaptation was found to be managed by fear of COVID-19. The fear of COVID-19 buffered the relationship between stress and the sense of coherence, weakening the impact of stress on the sense of coherence. Mertens et al. (2020) conducted an online survey $(\mathrm{N}=439)$ three days after the World Health Organization declared the coronavirus outbreak a pandemic (i.e., between 14-17 March 2020) to determine the predictors of coronavirus fear. As a result of the Coronavirus Fear Questionnaire (FCQ), they found four predictors: health anxiety, regular media use, social media use, and the risks to loved ones. In addition, 16 different concerns were identified based on the open-ended responses of the participants, including the health of loved ones, overload of health care systems, and economic consequences. Ren et al. (2020) analyze the underlying causes of discrimination and prejudice arising from fear or misinformation that jeopardize treatment efforts globally in tackling the COVID-19 pandemic and suggest practical solutions. Yildırım et al. (2020) examined the mediating roles of resilience and fear of coronavirus in the relationship between perceived risk and mental health problems among healthcare professionals, including physicians and nurses actively treating patients confirmed with COVID-19. The results showed that perceived risk and fear of coronavirus positively predicted depression, anxiety, and stress, while resilience negatively predicted mental health problems. Fear of coronavirus mediated the relationship between perceived risk and resilience, depression, anxiety, and stress; however, endurance mitigated the impact of coronavirus fear on depression, anxiety, and stress. Since several studies conducted during Covid-19 have shown that the pandemic increases the depression and anxiety levels (Wang et al., 2020) of individuals and the process produced various negative consequences among healthcare workers, as burnout (Chen et al., 2020) and 
sleep disturbances (Baykal, 2020), It is expected that this study will contribute to the literature in terms of revealing whether healthcare workers have the stated health problems due to the pandemic. Furthermore, unlike previous research, the study's use of psychological resilience as a mediator variable in the influence of coronavirus anxiety on life satisfaction is one of the study's unique features.

\section{METHOD}

\section{Participants}

The sample of this study consisted of health professionals taking active roles during the COVID-19 outbreak and living in various provinces of Turkey. Data collection took place between 28th July and 10th September 2020 online. By utilizing snowball and convenience sampling, 414 health professionals from 36 cities in Turkey participated in this study. $40.8 \%$ of participants were doctors, $33.3 \%$ were nurses, and $25.8 \%$ were other care workers (e.g., medical/laboratory assistants). Of the participants, $86.5 \%$ belonged to no history of chronic disease. Among all the participants, $17.4 \%$ were reported confirmed history of COVID-19 symptoms so far. They mostly had moderate socioeconomic status (83.1\%) and $88.9 \%$ were living with the people who are over the age of 65 at home. Detailed information on the participants is shown in Table 1.

\section{Table 1. Descriptive information of the participants}

\begin{tabular}{lcc}
\hline & $\mathrm{n}$ & $\%$ \\
\hline Gender & 158 & 38,2 \\
\hline Female & 256 & 61,8 \\
Male & 107 & 40.8 \\
\hline Job & 169 & 33.3 \\
\hline Doctor & 138 & 25.8 \\
Nurse & & \\
Other Healthcare professionals (e.g., medical/laboratory assistant) & 208 & 50.2 \\
\hline Age & 126 & 30.4 \\
\hline $18-29$ & 62 & 15.0 \\
$30-39$ & 16 & 3.9 \\
$40-49$ & 2 & .5 \\
$50-59$ & & \\
60 and over & 46 & 11,1 \\
\hline Living with over the age of 65 at home & 368 & 88.9 \\
\hline Yes & & \\
No & 56 & 13.5 \\
\hline Chronic (Asthma, Diabetes, Blood Pressure, COPD, etc.) disease & 358 & 86.5 \\
\hline Yes & & \\
No & 72 & 17.4 \\
\hline COVID 19 symptoms so far & 342 & 82.6 \\
\hline Yes & & \\
No & 18 & 4.3 \\
\hline Socio-economic condition & 344 & 83.1 \\
\hline Low & 52 & 12.6 \\
Moderate & &
\end{tabular}

\section{Ethical Statement}

The authors declare that they continue to work in accordance with scientific study ethics and the Helenski declaration in this study. Accordingly, the research was reviewed by the Scientific Research and 
Publication Ethics Committee of Duzce University and was given permission (Date: 22/01/2021, Number: E-96600542-300-7097). In addition, the participants participated in the study on a voluntary basis.

\section{Measures}

Demographic Characteristics: The socio-demographic variables used in the study included gender (men vs. women), age ranges (e.g., 18-29, 30-39, etc.), type of job (e.g., doctor, nurses, etc.), whether having a chronic illness or not, whether living with over the age of 65 at home or not, whether having COVID 19 symptoms so far or not and, the socioeconomic status.

The Fear of COVID-19 Scale: Ahorsu et al. (2020) developed the scale of the fear of COVID-19. This scale includes 7 items, and it is a unidimensional five-point Likert type scale ranging from 1 (Strongly disagree) to 5 (Strongly agree). Cronbach's alpha as an internal consistency coefficient for reliability analysis of the developed scale was 0.82 while the composite reliability of the scale was 0.88 . The total factor loads of items ranged between .66 and .74 and item-total correlations change between .47 and .50 . The scores of the scale were between 7 and 35, which low scores indicate low coronavirus fear. Sample items in this scale include "I am afraid of losing my life because of the coronavirus". Haktanir et al. (2016) adapted the fear of the COVID scale to the Turkish language while there were other researchers as Satici et al. (2020) and Bakioğlu et al. (2020) also made an adaptation of this scale to the Turkish language. The internal consistency of the adapted scale to Turkish by Haktanir et al. (2020) was 0.86, which is a little higher than the original form of the instrument. Also, the total factor loads of the adapted items ranged between 0.50 to 0.81 . In addition, while the internal consistencies of the adapted scale to Turkish by Satici et al. (2020) and Bakioğlu et al. (2020) were .84 and .88 respectively, the total factor loads of these adapted scale' items ranged between .48 to .72 and .73 to .82 respectively. Further, the measure had a strong internal reliability estimate with the current study (.89).

Brief Resilience $\boldsymbol{S}$ cale: This scale was developed by Smith et al. (2008) to measure an individual's ability to overcome difficult situations and recover from adversity and stress. Internal consistency that makes for reliability analyses was good, which Cronbach's alpha values ranging from .80 to .91. The scale includes 6 items, and it is a unidimensional Likert-type scale. Each question consists of five potential responses rating from 1 (Strongly disagree) to 5 (Strongly agree). The scores of the scale were between 6 and 30, which high scores indicate high resilience. Questions 2, 4, and 6 were reverse coded in the scale, and the scores of the scale calculated the sum of all six questions. Sample items in this scale include "It is hard for me to snap back when something bad happens". The scale has indicated acceptable to excellent reliability coefficient values in various studies ranged between 0.78 and 0.91 (Haktanir et al., 2018; Karaman et al., 2018; Smith et al., 2008). The measure had an adequate internal reliability estimate in the present study (.79).

Life Satisfaction Scale: Diener et al. (1985) developed the Satisfaction with Life Scale to measure the satisfaction of people with their present situation. Cronbach's alpha as an internal consistency coefficient was 0.87 while item-total correlations change 0.66 to 0.81 . The scale seems to have perfect test-re-test reliability with having a correlation of 0.82 . It has a single dimension Likert type-scale, and each question consists of five potential responses ranging from Strongly disagree (1) to Strongly agree (7). Sample items in this scale include "I am satisfied in my life". The scores range from 5 to 35 . The participants that get high scores show high levels of life satisfaction. Durak et al. (2010) adapted SWLS (Satisfaction with Life Scale) into the Turkish language. Also, Durak et al. (2010) reported that the reliability $(\alpha=.80)$ and the 
validity $(\mathrm{CFI}=.99, \mathrm{TLI}=.98, \mathrm{RMSEA}=.043, \mathrm{IFI}=.99$ and SRMR $=.020)$ of Turkish adaption of the SWLS was good. The reliability coefficient of the SWLS scale of the current study was satisfactory in the current study (.88).

\section{Procedure}

First, we sent an e-mail to Haktanir et al. (2020), the authors that adapted the fear of COVID original scale in the Turkish language and requested permission to use it for this study. The corresponding author shared the adapted scale and the guidelines for it. Then, an application of the ethics committee was submitted, and it was approved by the authors' university. Then, an online survey was created containing a study information sheet, the Turkish version of the fear of COVID-19, the Turkish version of the life satisfaction, and the Turkish version of the brief resilience scale and demographic questionnaire without any item jeopardizing the confidentiality. Volunteers who accepted to participate in the survey only were included with a giving guarantee of anonymity and privacy of given identifying information. After that, starting to authors' near online social environment and requesting them to share the questionnaire with health professionals in their environments, the questionnaire was distributed through an online data collection platform. Since there is big lockdowns and social and physical distance requirement is vital due to COVID-19, online data collection would be the best option in this fearful environment. Also, sharing the study link on social media accounts enabled us to reach a diverse population of 36 cities in Turkey.

\section{Data Analysis}

Data were analyzed through IBM SPSS Statistics 25 and IBM Amos 23. Investigation of descriptive statistics of the study variables and the relationships between all variables using Pearson correlation analysis was done, primarily. The normality was checked through skewness and kurtosis values, as well as their cut points (D'Agostino et al., 1990; Kline, 2015). After examining these analyses, confirmatory factor analysis for Fear of Coronavirus scale with the current study data. Further, a mediation analysis was conducted to investigate the proposed model for indirect effects suggesting that the association between the Fear of Coronavirus (FOC) and the Life Satisfaction (LS) may be mediated by the Psychological Resilience (PR) using path analysis on SPSS AMOS.

The fear of coronavirus variable was regressed on the life satisfaction variable, initially. The fear of coronavirus variable was also regressed with the psychological resilience variable, the mediator, on the life satisfaction variable. The estimations of maximum likelihood were used in these regressions. Following the suggestions of Preacher and Hayes (2008), the model of mediation effect was investigated with the bootstrap sample set to 5000 estimates and with the bootstrap confidence intervals of $95 \%$. The measured effect was considered insignificant when zero appeared from the confidence interval. To evaluate the model fit, Tucker Lewis index (TLI) and comparative fit index (CFI) (both 0.95 indicating a good fit), RMSEA (the root mean square error of approximation)( 0.08 indicating acceptable fit), and chisquare test were used with the following recommendations of Kline (2011).

\section{RESULTS}

\section{Confirmatory Factor Analysis}

We initially investigated the factor structure of the FOC with the sample of the current study using AMOS version 23 to conduct the confirmatory factor analysis. Findings from factor analysis were evaluated with 
the fit statistics of the data model and decision scores of them: GFI value $>.90=$ good fit; IFI value between .90 and $.95=$ acceptable fit; TLI and CFI scores $>.95$ close and the values between .90 and $.95=$ acceptable fit; SRMR and RMSEA values ranging from. 05 to $.10=$ acceptable and the values $<.05=$ close fit (Kline, 2015; Seçer, 2013; Hooper et al., 2008).

The results of confirmatory factor analysis showed that the measurement model, structured each of the seven items as the indicators of a single latent construct (i.e., fear of coronavirus), provided acceptable and good fit statistics of data-model $(x 2=16.91, \mathrm{df}=7, \mathrm{p}<.001, \mathrm{GFI}=.98, \mathrm{IFI}=.99$, $\mathrm{TLI}=.98, \mathrm{CFI}=.99$, RMSEA =.059, SRMR=.032). Moreover, the findings indicated that the fear of coronavirus scale had strong factor loadings, changing between .77 and .85 , as shown in Table 2.

\begin{tabular}{lccc}
\hline Table 2. Confirmatory factor analysis of the Fear of Coronavirus Scale & & \\
\hline Item & $\lambda$ & $\ell^{2}$ & $\mathrm{H}$ \\
\hline 1. I am most afraid of coronavirus-19 & .76 & .82 & .91 \\
2. It makes me uncomfortable to think about coronavirus-19 & .78 & .67 & - \\
3. My hands become clammy when I think about coronavirus-19 & .63 & .59 & - \\
4. I am afraid of losing my life because of coronavirus-19 & .84 & .52 & - \\
5. When watching news and stories about coronavirus-19 on social media, & .78 & .64 & - \\
I become nervous or anxious & .54 & .70 & - \\
6. I cannot sleep because I'm worried about getting coronavirus-19. & .60 & .53 & - \\
7. My heart races or palpitates when I think about getting coronavirus-19. &
\end{tabular}

Note. $\lambda=$ first-order factors' item loadings; $\ell 2=$ factor items' indicator reliability, $\mathrm{H}=$ reliability estimate of latent construct

Further, internal reliability and reliability of latent construct estimates of the FOC scale were strong $(\alpha=.89$ and $\mathrm{H}=.91)$. Thus, these findings give further evidence indicating that the FOC scale has a reliable and valid measure to evaluate the fear of coronavirus in Turkish healthcare professionals.

\section{Descriptive Statistics}

Descriptive statistics revealed that skewness and kurtosis ranged between -.53 to .79 , representing that all variables were normally distributed (D'Agostino et al., 1990; Abbott, 2011; Pituch and Stevens, 2015), as can be seen in Table 3. Further, correlation analysis results indicated that the fear of coronavirus had significant and negative correlations with the life satisfaction $(r=-.10, p<.05)$ and psychological resilience $(\mathrm{r}=-.29, \mathrm{p}<.01)$. The psychological resilience had significant and positive correlations with the life satisfaction $(\mathrm{r}=.32, \mathrm{p}<.01)$.

Table 3. Descriptive statistics and Pearson correlation coefficients the Variables

\begin{tabular}{lcccccccc}
\hline \multicolumn{8}{c}{ Descriptive Statistics } \\
\hline Scale & $\mathrm{M}$ & SD & Skew. & Kurt. & $\alpha$ & 1 & Correlations \\
\hline 1. FOC & 2.37 & .91 & .79 &, 25 & .89 & - & 2 & 3 \\
2.PR & 3.27 & .80 & .09 & -.22 & .79 &,$- 29 * *$ & - & \\
3.LS & 4.17 & 1.37 & -.23 & -.53 & .88 &,$- 10^{*}$ &, $32^{* *}$ & - \\
\hline
\end{tabular}

Note. $\mathrm{FOC}=$ Fear of Coronavirus, $\mathrm{PR}=$ Psychological Resilience, LS= Life Satisfaction $*_{\mathrm{p}}<.05,{ }^{*} \mathrm{p}<.01$

\section{Mediation Model}

The representation of the path model with the items obtained from the IBM Amos 23 program was shown in Figure 1. Mediation analysis was conducted to reveal how psychological resilience contributed to the association between fear of coronavirus and life satisfaction among healthcare professionals. The results of mediation analysis indicated that the measurement model, structured each of the seven items of the fear of coronavirus, six items of the psychological resilience, and five items of the life satisfaction 
indicators of three latent constructs, provided a satisfactory model fit statistics $(x=341.69, \mathrm{~d} f=126, \mathrm{p}<$ $.01, \mathrm{GFI}=.92, \mathrm{AGFI}=.88 \mathrm{NFI}=91$, $\mathrm{IFI}=0,94, \mathrm{TLI}=.93, \mathrm{CFI}=.94, \mathrm{RMSEA}=.064, \mathrm{SRMR}=.064)$.

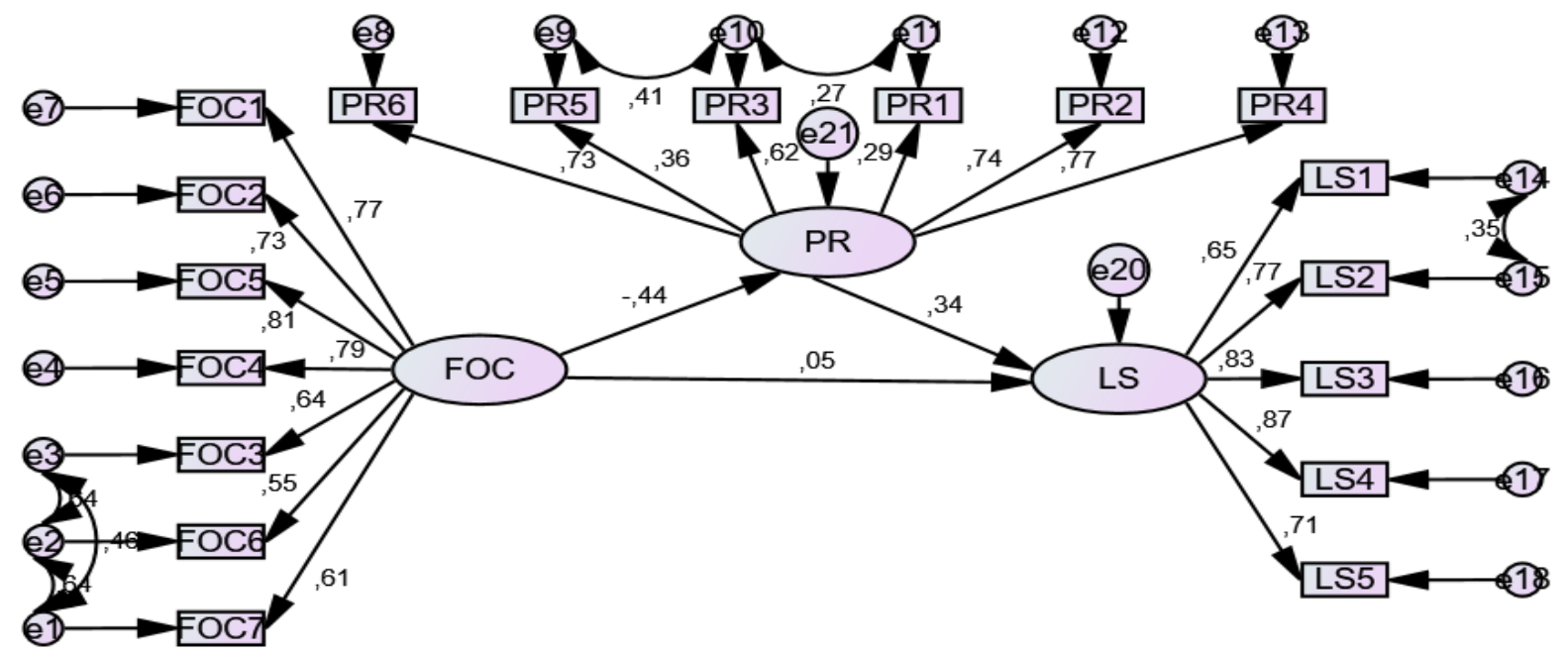

Figure 1. The structural model with the items obtained from IBM Amos 23 program.

Also, fear of coronavirus had a significant effect on life satisfaction before mediation analyses (see Table 4). On the other hand, fear of coronavirus had a non-significant direct effect when mediating psychological resilience on life satisfaction. This shows that there is a full mediation with respect to the classical approach as Baron and Kenny (1986) suggested. Fear of coronavirus had a significant effect on psychological resilience after mediation analyses, as seen in both standardize coefficient $(\beta=.44, \mathrm{p}<.01)$ in Figure 1 and unstandardized coefficient $(.53, \mathrm{p}<.01)$ indicated with Table 4 . The same results were also valid for the association between psychological resilience and life satisfaction, which the former had a significant effect on the latter proved both standardized direct effect $(\beta=.34, \mathrm{p}<.01)$ in Figure 1 and unstandardized indirect effect $\beta=.41, \mathrm{p}<.01$ shown in Table 4 .

\begin{tabular}{cccccl}
\hline \multicolumn{7}{c}{ Table 4. Unstandardized coefficients for the Structural Model before and after mediation } \\
\hline \multicolumn{7}{c}{ (Before Mediation) } \\
\hline Hypothesis & Paths & Estimate $(\beta)$ & S.E. & C.R. & P \\
\hline $\mathrm{H}_{1}$ & LS <--- FOC & -.16 & .08 & -2.00 & .045 \\
\hline & (After Mediation) \\
& Paths & Estimate $(\beta)$ & S.E. & C.R. & P \\
\hline \multirow{2}{*}{$\mathrm{H}_{2}$} & PR <--- FOC & -.53 & .08 & -6.82 & $* * *$ \\
& LS <--- PR & .41 & .08 & 4.88 & $* * *$ \\
LS <--- FOC & .08 & .09 & .85 & .39 \\
\hline
\end{tabular}

Note. FOC $=$ Fear of Coronavirus, $\mathrm{PR}=$ Psychological Resilience, $\mathrm{LS}=$ Life Satisfaction

$* * *=$ Completely significant

All variables in the path model together, explained $10,3 \%$ of the variance in life satisfaction while fear of coronavirus explained \%19,6 of the psychological resilience. Further, the indirect effect of fear of coronavirus on life satisfaction through psychological resilience was also significant, as shown in Table 5. This table also indicated that psychological resilience significantly mediated the analyzed relationships with respect to the modern approach of the bootstrap method that suggesting lower and upper confidence intervals never include zero (Preacher and Hayes, 2004; Friz and MacKinnon, 2007; Hayes, 2018). These results suggest that psychological resilience is an important mechanism that may contribute 
to understanding the association between fear of coronavirus and life satisfaction thoughts in healthcare professionals.

Table 5. The completely standardized indirect effect of fear of coronavirus on life satisfaction

\begin{tabular}{ccccc}
\hline Indirect Path & Total indirect effect & SE & BootLLCI & BootULCI \\
\hline LS<--- PR <--- FOC & -.151 & .07 &,- 59 &,- 14 \\
\hline
\end{tabular}

Note. Number of bootstrap samples for percentile bootstrap confidence intervals: 10,000

\section{DISCUSSION, CONCLUSION \& SUGGESTIONS}

Fear is an adaptive, protective mechanism for animals and humans, underpins survival, and involves several biological processes aimed at preparing to respond to potentially dangerous events. But when it is chronic or disproportionate, it becomes harmful and can be an important component in the development of various mental disorders (Garcia, 2017; Shin and Liberzon, 2010). Therefore, in this study, the effect of coronavirus fear on psychological resilience and life satisfaction was examined. According to the results of the study, when the standardized values of the total effects are examined, it has been seen that the fear of coronavirus had significant and negative correlations with life satisfaction and psychological resilience. Also, fear of coronavirus had a negative significant effect on life satisfaction before mediation analyses. Moreover, fear of coronavirus had a non-significant direct effect when mediating psychological resilience on life satisfaction. Further, fear of coronavirus had a significant effect on psychological resilience after mediation analyses. The same results were also valid for the association between psychological resilience and life satisfaction. Psychological resilience had significant and positive correlations with life satisfaction. Within the framework of these results, it has been observed that the increase in the fear of coronavirus decreases the levels of Psychological Resilience and Life Satisfaction, whereas the increase in Psychological Resilience increases the level of Life Satisfaction. All variables in the path model together, explained $10,3 \%$ of the variance in life satisfaction while fear of coronavirus explained \%19,6 of the psychological resilience. Further, the indirect effect of fear of coronavirus on life satisfaction through psychological resilience was also significant. These results suggest that psychological resilience is an important mechanism that may contribute to understanding the association between fear of coronavirus and life satisfaction thoughts in healthcare professionals.

Studies conducted after Covid-19 have shown that the pandemic increases the depression and anxiety levels (Wang et al., 2020) of individuals and their suicidal tendencies (Mamun and Griffiths, 2020); and showed that the process produced various negative consequences among healthcare workers, such as burnout (Chen et al., 2020), loneliness (Zandifar and Badrfam, 2020), and sleep disturbances (Huang and Zhao, 2020; Baykal, 2020). Findings in this study were obtained to support the idea that individuals with higher levels of resilience tend to cope with stressful events more successfully than those with lower resilience (Haktanir et al., 2020; Haktanir et al., 2018; Smith et al., 2017). Similarly, Hjemdal et al. (2011) stated that individuals with high psychological resilience are less depressed, less stressed about events, and less anxious; as a result, he argues that their life satisfaction levels are higher. Also similar to the results we found, Dymecka et al. (2020) found a statistically significant relationship between fear of COVID-19 and life satisfaction during the coronavirus outbreak; Naeem et al. (2020) argue that individuals who actively develop positive emotions have higher psychological resilience. The research of Evren et al. (2020) revealed that individuals worried about COVID-19 have lower life satisfaction and low life satisfaction levels cause them to experience negative feelings about the disease. Similar to our study, there are studies demonstrating the negative effect of anxiety on quality of life and satisfaction in 
the Covid-19 process in Turkey (Çiçek and Almalı, 2020; Kul et al., 2020; Tekin, 2020). In the international literature, there are empirical studies showing the negative relationship of anxiety levels of individuals in the Covid process on their life satisfaction, and they are in line with the result of our study (Rogowska et al., 2020; Tomaszek and Muchacka-Cymerman, 2020; Dymecka et al., 2020). Positive emotions have been found to decline in the wake of the COVID-19 pandemic (S. Li et al., 2020; Bozdağ and Ergün, 2020). Therefore, as Buheji et al. (2020) and Bozdağ and Ergün (2020) stated, governments and particularly medical leaders should focus on changing people's minds and thus increasing their psychological resilience levels.

There are a few shortcomings in this research. Because the number of respondents is small in comparison to the overall number of healthcare workers in Turkey, it is possible that the results may not reflect the full group of healthcare workers. However, sampling in this study was limited due to a lack of money, the quarantine process, and the exhaustion of health workers involved in this process.

The study results show that COVID-19 fear can result in considerable life dissatisfaction for healthcare professionals and psychological resilience can reduce this situation. Healthcare managers, health officials, and psychologists need to be made aware of this issue and take necessary precautions. They must work to specify other factors that influence COVID-19 fear and life satisfaction relation to provide a healthy healthcare staff who are in the high-risk group. It is also suggested that countrywide epidemiological research is urgently needed to evaluate the amount of anxiety, worry, and helplessness, as well as other related mental health concerns, in relation to COVID-19. This would aid in the development of focused mental health initiatives (e.g., such as those who live in a rural area). 


\section{REFERENCES}

Abbott, M. L. (2011). Understanding educational statistics using Microsoft Excel and SPSS. United States: John Wiley \& Sons Inc.

Ahmed, M. A., Jouhar, R., Ahmed, N., Adnan, S., Aftab, M., Zafar, M. S., \& Khurshid, Z. (2020). Fear and practice modifications among dentists to combat novel coronavirus disease (COVID-19) outbreak. International Journal of Environmental Research and Public Health, 17(8), 2821. https://doi.org/10.3390/ijerph17082821

Ahorsu, D. K., Lin, C., Imani, V., Saffari, M., Griffiths, M. D., \& Pakpour, A. H. (2020). The fear of COVID-19 scale: Development and initial validation. International Journal of Mental Health and Addiction, 1-9. https://doi.org/10.1007/s11469-020-00270-8

Amin, S. (2020). The psychology of coronavirus fear: Are healthcare professionals suffering from corona-phobia?
International
Journal
of Healthcare
Management,
13(3),
249-256.

https://doi.org/10.1080/20479700.2020.1765119

Arslan, G., Yildirim, M., Tanhan, A., Bulus, M., \& Allen, K. A. (2020). Coronavirus stress, optimism-pessimism, psychological inflexibility, and psychological health: Psychometric properties of the Coronavirus Stress Measure. International Journal of Mental Health and Addiction, 1-17. https://doi.org/10.1007/s11469-020$\underline{00337-6}$

Bakioglu, F., Korkmaz, O., \& Ercan, H. (2020). Fear of COVID-19 and positivity: Mediating role of intolerance of uncertainty, depression, anxiety, and stress. International Journal of Mental Health and Addiction, 1-14. https://doi.org/10.1007/s11469-020-00331-y

Baron, R. M., \& Kenny, D. A. (1986). The moderator-mediator variable distinction in social psychological research: Conceptual, strategic, and statistical considerations. Journal of Personality and Social Psychology, 51(6), 1173. https://doi.org/10.1037/0022-3514.51.6.1173

Baykal, E. (2020). COVID-19 baglaminda psikolojik dayaniklilik, kaygi ve yasam doyum iliskisi Relationship of psychological resilience, anxiety, and life satisfaction in the context of COVID-19]. International Journal of Social and Economic Sciences, 10(2), 68-80. https://dx.doi.org/10.7827/TurkishStudies.43492

Belen, H. (2021). Fear of COVID-19 and mental health: The role of mindfulness in during times of crisis. International Journal of Mental Health and Addiction, 1-12. https://doi.org/10.21203/rs.3.rs-40529/v

Bozdag, F. and Ergün, N. (2020). Psychological Resilience of Healthcare Professionals During COVID-19 Pandemic. Sage Journals, 1-20. https://doi.org/10.1177/0033294120965477

Chaudhary, N. K. (2020). Outbreak of coronavirus disease (COVID-19). Journal of Chitwan Medical College, 10(1), 12. https://doi.org/10.3126/jcmc.v10i1.28059

Chen, S., \& Bonanno, G. A. (2020). Psychological Adjustment During the Global Outbreak of COVID-19: A Resilience Perspective. Psychological Trauma: Theory, Research, Practice, and Policy, 12(S1), 51-55. https://doi.org/10.1037/tra0000685

Çiçek, B., \& Almali, V. (2020). COVID-19 Pandemisi sürecinde kaygi öz-yeterlilik ve psikolojik iyi olus arasindaki iliski: Özel sektör ve kamu calisanlari karsilastirmasi [The Relationship between anxiety self-efficacy and psychological well-being in the COVID-19 pandemic process: Comparison of private sector and public servants]. Electronic Turkish Studies, 15(4), 241-260. https://doi.org/10.7827/turkishstudies.43492

D’Agostino, R. B., Belanger, A., \& D’Agostino, R. B. (1990). A suggestion for using powerful and informative tests of normality. The American Statistician, 44(4), 316-321. https://doi.org/10.2307/2684359

Diener, E. D., Emmons, R. A., Larsen, R. J., \& Griffin, S. (1985). The satisfaction with life scale. Journal of Personality Assessment, 49(1), 71-75. https://doi.org/10.1207/s15327752jpa4901 13 
Doshi, D., Karunakar, P., Sukhabogi, J. R., Prasanna, J. S. and Mahajan, S. V. (2020). Assessing coronavirus fear in Indian population using the fear of COVID-19 scale. International Journal of Mental Health and Addiction, 1-9. https://doi.org/10.1007/s11469-020-00332-x

Duncan, L. A., Schaller, M., \& Park, J. H. (2009). Perceived vulnerability to disease: Development and validation of a 15-item self-report instrument. Personality and Individual Differences, 47(6), 541-546. https://doi.org/10.1016/i.paid.2009.05.001

Durak, M., Senol-Durak, E., \& Gencoz, T. (2010). Psychometric properties of the satisfaction with life scale among Turkish university students, correctional officers, and elderly adults. Social Indicators Research, 99, 413-429. https://doi.org/10.1007/s11205-010-9589-4

Durmus, M., \& Durar, E. (2021). The relationship between spiritual well-being and fear of COVID-19 among Turkish elders. Journal of Religion, Spirituality \& Aging, 1-14. https://doi.org/10.1080/15528030.2021.1894627

Dymecka J., Gerymski R., Machnik-Czerwik A. (2021). How does stress affect life satisfaction during the COVID19 pandemic? Moderated mediation analysis of sense of coherence and fear of coronavirus. Psychol. Health Med., 31, 1-9. https://doi.org/10.1080/13548506.2021.1906436

Evren, C., Evren, B., Dalbudak, E., Topcu, M., \& Kutlu, N. (2020). Measuring anxiety related to COVID-19: A Turkish validation study of the coronavirus anxiety scale. Death Studies, 1-7. https://doi.org/10.1080/07481187.2020.1774969

Fritz, M. S., \& MacKinnon, D. P. (2007). Required sample size to detect the mediated effect. Psychological Science, 18(3), 233-239. https://doi.org/10.1111/j.1467-9280.2007.01882.x

Garcia R. (2017). Neurobiology of fear and specific phobias. Learning \& Memory (Cold Spring Harbor, N.Y.), 24(9), 462-471. https://doi.org/10.1101//m.044115.116

Guo, Y. R., Cao, Q. D., Hong, Z. S., Tan, Y. Y., Chen, S. D., Jin, H. J., ... \& Yan, Y. (2020). The origin, transmission and clinical therapies on coronavirus disease 2019 (COVID-19) outbreak-an update on the status. Military Medical Research, 7(1), 1-10. https://doi. org/10.1186/s40779-020-00240-0

Haktanir, A., Lenz, A.S., Can, N., Watson, J. C. (2016). Development and evaluation of Turkish language versions of three positive psychology assessments. International Journal of Advancement in Counselling; 38(4), 286297. https://doi.org/10.1007/s10447-016-9272-9

Haktanir, A., Seki, T., \& Dilmaç, B. (2020). Adaptation and evaluation of Turkish version of the fear of COVID19 scale. Death Studies, 1-9. https://doi.org/10.1080/07481187.2020.1773026

Haktanir, A., Watson, J. C., Ermis-Demirtas, H., Karaman, M. A., Freeman, P. D., Kumaran, A., \& Streeter, A. (2021). Resilience, academic self-concept, and college adjustment among first-year students. Journal of College Student Retention: Research, Theory \& Practice, 23(1), 161-178. https://doi.org/10.1177/1521025118810666

Hayes, A. F. (2018). Partial, conditional, and moderated moderated mediation: Quantification, inference, and interpretation. Communication Monographs, 85(1), 4-40. https://doi.org/10.1080/03637751.2017.1352100

Hjemdal, O., Vogel, P. A., Solem, S., Hagen, K., \& Stiles, T. C. (2011). The relationship between resilience and levels of anxiety, depression, and obsessive-compulsive symptoms in adolescents. Clinical Psychology \& Psychotherapy, 18(4), 314-321. https://doi.org/10.1002/cpp.719

Holmes, K. V. (2003). SARS-associated coronavirus. New England Journal of Medicine, 348(20), 1948-1951. https://doi.org/10.1056/NEJMp030078

Huang, Y., \& Zhao, N. (2020). Generalized anxiety disorder, depressive symptoms and sleep quality during COVID-19 outbreak in China: A web-based cross-sectional survey. Psychiatry Research, 288, 112954. https://doi.org/10.1016/i.psychres 
Karaman, M. A., Chandrika Kumaran, A., Haktanir A., \& Lenz, S. (2018). Predictors of counselor-in-training students' general self-efficacy. Mediterranean Journal of Educational Research,12(25), 136-149. https://doi.org/10.29329/mjer.2018.153.8

Kline, R. B. (2011). Principles and practice of structural equation modeling. Guilford Press.

Kul, A., Demir, R., \& Katmer, A. N. (2020). COVID-19 salgini döneminde psikolojik saglamligin yordayicisi olarak yasam anlami ve kaygi [Life meaning and anxiety as the predictor of psychological resilience during the COVID-19 outbreak]. Electronic Turkish Studies, 15(6), 695-719. https://doi.org/10.7827/turkishstudies.44419

Mamun, M. A., \& Griffiths, M. D. (2020). First COVID-19 suicide case in Bangladesh due to fear of COVID-19 and xenophobia: possible suicide prevention strategies. Asian Journal of Psychiatry, 51, 102073. https://doi. org/10.1016/j.ajp.2020.102073.

Mertens, G., Gerritsen, L., Duijndam, S., Salemink, E. and Engelhard, I.M. (2020). Fear of the coronavirus (COVID-19): Predictors in an online study conducted in March 2020. Journal of Anxiety Disorders, 74, 102258. https://doi.org/10.1016/j.janxdis.2020.102258

Pappas, G., Kiriaze, I. J., Giannakis, P., \& Falagas, M. E. (2009). Psychosocial consequences of infectious diseases. Clinical Microbiology and Infection, 15(8), 743-747. https://doi.org/10.1111/j.1469-0691.2009.02947.x

Pituch, K. A., \& Stevens, J. P. (2015). Applied multivariate statistics for the social sciences: Analyses with SAS and IBM's SPSS. 6th Edition, Routledge, Taylor \& Francis Group. https://doi.org/10.4324/9781315814919

Preacher, K. J., \& Hayes, A. F. (2004). SPSS and SAS procedures for estimating indirect effects in simple mediation models. Behavior Research Methods, Instruments, \& Computers, 36(4), 717-731. https://doi.org/10.3758/bf03206553

Ren, S. Y., Gao, R. D., \& Chen, Y. L. (2020). Fear can be more harmful than the severe acute respiratory syndrome coronavirus 2 in controlling the corona virus disease 2019 epidemic. World Journal of Clinical Cases, 8(4), 652. https://doi.org/10.12998/wjcc.v8.i4.652

Rogowska, A. M., Kusnierz, C., \& Bokszczanin, A. (2020). Examining anxiety, life satisfaction, general health, stress and coping styles during COVID-19 pandemic in Polish sample of university students. Psychology Research and Behavior Management, 13, 797. https://doi.org/10.2147/prbm.s266511

Ropeik, D. (2004). The consequences of fear. EMBO Reports, 5(Suppl 1), 56-60. https://doi.org/10.1038/sj. embor.7400228

Satici, B., Gocet-Tekin, E., Deniz, M. E., \& Satici, S. A. (2020). Adaptation of the Fear of COVID-19 Scale: Its association with psychological distress and life satisfaction in Turkey. International Journal of Mental Health and Addiction, 1-9. https://doi.org/10.1007/s11469-020-00294-0

Seçer, I. (2013). SPSS ve LISREL ile pratik veri analiẓi [Practical data analysis with spss and lisrel: Analysis and reporting]. Ani Yayincilik.

Shin, L. M., \& Liberzon, I. (2010). The neurocircuitry of fear, stress, and anxiety disorders. Neuropsychopharmacology, 35(1) 169-191. https://doi.org/10.1038/npp.2009.83

Smith, B. W., Dalen, J., Wiggins, K., Tooley, E., Christopher, P., \& Bernard, J. (2008). The brief resilience scale: Assessing the ability to bounce back. International Journal of Behavioral Medicine, 15(3), 194-200. https:// doi.org/10.1080/10705500802222972

Smith, L. B., Lenz, A. S., \& Strohmer, D. (2017). Differential prediction of resilience among individuals with and without a history of abuse. Counseling and Values, 62(1), 106-122. https://doi.org/10.1002/cvj.12052

Tekin, E. (2020). COVID-19 kaygisinin motivasyon üzerindeki etkisi: Z kusagi üzerine bir arastirma [The impact of covid-19 anxiety on motivation: A study on generation z]. Electronic Turkish Studies, 15(4), 1129-1145. https://doi.org/10.7827/turkishstudies.44070 
Tomaszek, K., \& Muchacka-Cymerman, A. (2020). Thinking about my existence during COVID-19, I feel anxiety and awe-the mediating role of existential anxiety and life satisfaction on the relationship between ptsd symptoms and post-traumatic growth. International Journal of Environmental Research and Public Health, 17(19), 7062. https://doi.org/10.3390/ijerph17197062

Wang, C., Pan, R., Wan, X., Tan, Y., Xu, L., McIntyre, R. S., ... \& Ho, C. A. (2020). A longitudinal study on the mental health of general population during the COVID-19 epidemic in China. Brain, Behavior, and Immunity, (87), 40-48. https://doi.org/10.1016/j.bbi.2020.04.028

World Health Organization (2020a). Q\&A on coronaviruses (COVID-19). https://www.who.int/news-room/q-adetail/q-a-coronaviruses\#: $\sim:$ text=symptoms

World Health Organization (2020b). WHO Director-General's opening remarks at the media briefing on COVID-19. https://www.who.int/dg/speeches/detail/whodirector-general-s-opening-remarks-at-the-mediabriefing-on-covid-19\%2D \%2D-18-march-2020

World Health Organization (2020c). Report of the WHO-China Joint Mission on Coronavirus Disease 2019 (COVID-19). https://www.who.int/docs/default-source/coronaviruse/whochina-joint-mission-on-covid-19-finalreport.pdf

World Health Organization (2020d). WHO Director-General's opening remarks at the media briefing on COVID-19. https://www.who.int/dg/speeches/detail/whodirector-general-s-opening-remarks-at-the-mediabriefing-on-covid-19\%2D \%2D-3-march-2020

Yildirim, M., Arslan, G., \& Özaslan, A. (2020). Perceived risk and mental health problems among healthcare professionals during COVID-19 pandemic: exploring the mediating effects of resilience and coronavirus fear. International Journal of Mental Health and Addiction, 1-11. https://doi.org/10.31234/osf.io/84xju

Zandifar, A., \& Badrfam, R. (2020). Iranian mental health during the COVID-19 epidemic. Asian Journal of Psychiatry, 51, 101990. https://doi.org/10.1016/j.ajp.2020.101990 


\begin{abstract}
About Authors
Yalçın Karagöz. He completed his undergraduate education in the field of Mathematics Teaching at Atatürk University in 1989. Afterwards, he completed his master's degree in 1995 at Sivas Cumhuriyet University and; completed his doctorate at Sivas Cumhuriyet University in 2002. He is still working as a professor at Duzce University, Faculty of Business Administration, Healthcare Management Department.
\end{abstract}

İsmail Durak. He completed his B.S. degree in elementary mathematics education from Middle East Technical University in 2010, the M.S. degree in business administration from Duzce University in 2014 and the Ph.D. degree in quantitative methods from Istanbul University in 2018. He is still working as an assistant professor at Duzce University, Faculty of Business Administration, Business Administration Department.

Hakan Tahiri Mutlu. He completed his undergraduate education at Bolu Abant Izzet Baysal University, Department of Mathematics (English) in 2010. He held his Master's degree in the field of Business Administration at Bolu Abant Izzet Baysal University in 2013. He held his doctorate degree in the field of Business Administration at Duzce University in 2020. He is still working as an assistant professor at Bolu Abant Izzet Baysal University, Business Administration Department.

\title{
Author Contributions
}

This study was conducted by all the authors working together and cooperatively. All of the authors substantially contributed to this work in each step of the study.

\section{Conflict of Interest}

It has been reported by the authors that there is no conflict of interest.

\section{Funding}

No funding support was recieved.

\section{Ethical Statement}

This study was completed in accordance with the Helsinki Declaration. In line with this, the study was permitted by Research and Publication Ethics Committee of Artvin Çoruh University.

Ethics Committee Name: Research and Publication Ethics Committee of Duzce University. Approval Date: 22/01/2021

Approval Document Number: E-96600542-300-7097 